\title{
Complementary Institutions in Authoritarian Regimes: The Everyday Politics of Constituency Service in Singapore
}

\section{Elvin Ong}

\begin{abstract}
Recent political science research has suggested that autocrats adopt a variety of institutions such as nominally democratic elections and ruling parties to buttress authoritarian durability. In this article I investigate the role of constituency service in an authoritarian regime. I argue that Singapore's Meet-the-People Sessions (MPS) is a complementary institution that can serve to mitigate the weaknesses of other authoritarian institutions, thereby entrenching authoritarianism, rather than serve as a form of democratic representation. First, it is a mechanism to gain valuable everyday information about grievances within the population, thereby allowing the ruling People's Action Party (PAP) to formulate policies and effectively target its response. Second, it is a convenient venue to recruit and socialize ordinary party members, thus helping the PAP forestall potential party decay. Symbolically, conducting MPS is a material performance of the hegemonic ideology of elitism between PAP politicians and ordinary Singaporeans. Keywords: authoritarian regimes, constituency service, political recruitment, hegemonic performance, Singapore
\end{abstract}

\section{The Puzzle}

Modern Singapore has been "one of the most outstandingly stubborn cases of authoritarianism" in East Asia (Sim 2006, 143), and is "the most economically developed nondemocracy in the history of the world" (Diamond 2012, 7). Its authoritarian turn arguably began when the ruling People's Action Party (PAP) achieved overwhelming victory in the 1959 internal legislative elections while still under British colonial rule, winning forty-three out of fifty-one seats. The PAP has not lost control of parliament since then. With the stated aim of achieving political order in a racially heterogeneous society and material progress for a tiny island nation, Lee Kuan Yew's PAP tightened its grip on the state through crack- 
ing down on civil society, censoring the press, curtailing general freedoms of expression and assembly, and marginalizing its political opponents (see, for example, Chua 2003; George 2007; Barr and Skrbiš 2009; Rajah 2012). With one of the highest per capita incomes in the world today, the endurance of authoritarianism in Singapore is a deviant case ${ }^{1}$ in a world where economically developed countries are typically liberal democracies.

I investigate how Singapore's Meet-the-People Sessions (MPS), an institution that resembles constituency service in advanced liberal democracies, actually works to contribute to the PAP's authoritarian durability. On a specific weekday evening, at a particular time, and at a particular location, ordinary Singaporeans turn up to meet their local legislative member to appeal to government authorities for various matters such as renting public housing, obtaining financial assistance, waiving traffic fines, or pleading for speedy processing of their immigration matters. ${ }^{2}$ The sole product is a letter of appeal sent by the legislative member to the relevant government authority to urge them to look into and resolve the issue. According to statistics compiled by Prime Minister Lee Hsien Loong for his own constituency service, in the whole year of 2012, he served "nearly 2,800 residents (many of whom came more than once) and wrote over 5,500 letters of appeal, or more than 100 letters per week." ${ }^{3}$ With a total of eighty-seven elected legislators meeting a very conservative average of about thirty residents a week throughout the entire year, an astounding approximately 135,720 appeal letters are generated through MPS every year.

That such a constituency service exists in an authoritarian regime is deeply puzzling in at least two ways. First, if a successful authoritarian regime controls all levers of government, why would it develop an institution that purports to solve a constituent's problem by writing appeal letters to itself? It appears paradoxical, hypocritical even, that highly paid and powerful legislative members spend so much time and effort to attend to such trivial disputes, when immediate intervention by a politician in the bureaucracy can resolve most problems. Second, in authoritarian regimes where elections are significantly and substantively less competitive due to the prevalence of electoral manipulation, there appears to be very little electoral incentive for legislators to engage in constituency service. In democracies, in contrast, we can expect legislative members to perform constituency service because doing so helps them generate goodwill for reelection. What reasons would motivate an authoritarian regime that effectively monopolizes political power to adopt such constituency service? 
Through the close analysis of MPS in Singapore and a theoretical engagement with the recent literature in comparative politics about the institutions of authoritarian regimes, I argue that the MPS functions as a complementary authoritarian institution. Complementary institutions are institutions that can support or augment the deficiencies of other institutions, thereby enhancing their efficiency or effectiveness (Hall and Soskice 2001, 17; Helmke and Levitsky 2006, 13-14). I posit that while complementary authoritarian institutions are neither necessary nor sufficient for authoritarian durability in and of themselves, they can work to help an autocrat stay in power for a much longer time by mitigating the flaws of its other key institutions. In Singapore, the weekly regular performance of constituency service serves three functions as a complementary institution. First, it allows the ruling party to gain information about and respond to everyday grievances in the population in between episodic elections. Second, the weekly regular gathering of party members also serves as a useful platform to recruit young volunteers into the party and build camaraderie among party members, hence forestalling potential ruling party decay. Finally, the consistent material performance of the MPS also demonstrates that hegemonic ideologies no longer exist as meaningless forms of propaganda or cheap talk, but can be translated into regular, not episodic, benefits for the masses. In sum, I advance a paradoxical argument that constituency service in an authoritarian regime serves to entrench authoritarianism and deter democratic pressures, rather than function as a mode of democratic representation. ${ }^{4}$

Overall, this article's account of Singapore's MPS as a complementary authoritarian institution is theoretically and empirically relevant to a wide range of audiences. Chinese scholars and politicians, for example, have enduring interests in understanding Singapore's MPS. When the former Guangdong Communist Party secretary and current vice premier Wang Yang returned from his visit to Singapore in 2008, he extolled the Chinese to learn from Singapore, which piqued the interest of the Chinese media to learn more about the MPS (Mu 2008). Two Chinese scholars who interviewed opposition leader Low Thia Khiang in 2013 noted how it was important for China to learn from Singapore's institutions such as its MPS in order to build better ties between the politicians and the masses (Zaobao 2013). More recently, when the Guangdong Communist Party Secretary Hu Chunhua visited Singapore in April 2014, he visited the MPS of Chan Chun Sing, the then Singaporean Minister for Social and Family Development. ${ }^{5}$

The article proceeds as follows: First, I contrast constituency service in advanced liberal democracies with constituency service in Singa- 
pore to further specify why it is so puzzling to observe constituency service in an authoritarian regime. Second, I review the existing literature on authoritarian institutions, critically examining how such institutions may be episodic and how they may potentially decay, and explicate how some institutions may be viewed as complementary institutions. Third, I solve the puzzle by arguing that MPS is a complementary authoritarian institution. The empirical section provides a broad array of evidence to demonstrate how MPS functions to mitigate the episodic nature of authoritarian elections, forestall potential ruling party decay, and render material hegemonic ideology. Evidence for this article was assembled using secondary materials, newspaper archives, publicly available online videos and news reports, archives of parliamentary reports, a dozen interviews with MPS volunteers, and a year's worth of ethnographic participation at an MPS. The conclusion discusses this article's implications for the empirical, theoretical, and normative study of authoritarian institutions.

\section{Democratic Constituency Service Versus Authoritarian Constituency Service}

Before turning to the theoretical and empirical analysis of MPS as a complementary authoritarian institution, it is worthwhile to elaborate why it is particularly puzzling to find constituency service in an authoritarian regime. In advanced liberal democracies, legislative members undertake constituency service to demonstrate their competency to their constituents, thereby generating goodwill and building reputations (Stokes et al. 2013, 14). The intuition is that performing constituency service helps parliamentarians, in part, to get reelected. In Richard Fenno's seminal book, Home Style: House Members in Their Districts, he describes constituency service as such:

For the congressman's staff - whether located in Washington or at home-constituent service is the most time-consuming activity. For the member of Congress, it is a highly valued form of activity. Not only is constituent service universally recognized as an important part of the job in its own right. It is also universally recognized as powerful reelection medicine. (Fenno 1978, 101)

As the quote suggests, the reelection motivation for a parliamentarian to conduct constituency service is obvious. In a survey conducted by Parker and Davidson (1979), 49.8 percent of survey respondents said that constituency service served as the primary basis of evaluation of their con- 
gressman. Cain, Ferejohn, and Fiorina (1984) posit that British members of parliament undertake constituency service to develop a reputation for themselves as an insurance against the declining popularity of their own party. To a large extent, the incentives for constituency service vary according to the electoral system and the competitiveness of the seat. In their analysis of five democratic parliamentary systems, Heitshusen, Young, and Wood (2005) find that legislative members in single-member plurality districts have a much higher probability of prioritizing constituency service compared to legislative members elected in multimember districts or proportional representation systems. Furthermore, legislative members in more marginal seats are also more likely to prioritize constituency service compared to safe seats, even after controlling for politician and district characteristics (Dropp and Peskowitz 2012). At the end of the day, candidates care about getting reelected, even if they end up as "errand boys" (Fiorina 1977, 179-181).

In contrast, the electoral impact of performing constituency service is much more ambiguous. Johannes and McAdams (1981) find that the vote share of an incumbent does not significantly increase with higher levels of constituency service. They suggest that "voters are ingrates" who have come to expect constituency service as a matter of course. Searing's (1985) survey and interviews of British members of parliament suggest that constituency service provides very little return on votes, and that their primary motivations were to cultivate "a sense of competence" or "a sense of duty." Indeed, if constituency service is provided in a nonpartisan manner and if a voter's vote is secret, then there is no way of exactly knowing if the provision of constituency service has any direct impact on electoral outcomes.

That politicians in advanced democratic polities are motivated to perform constituency service with an eye on reelection is apparent enough. What is uncertain is why politicians in an authoritarian regime like Singapore would be motivated to perform constituency service at all. Chan Heng Chee has noted that the PAP members of parliament are expected to conduct MPS "religiously," and that the PAP leadership has "reprimanded MPs [Members of Parliament] who were nonchalant in their acquittal of this responsibility" (Chan 1976, 436). The proliferation of literature on authoritarian regimes in political science does not provide any straightforward answers as it has largely focused on formal institutions of government such as ruling parties, authoritarian elections, and legislatures. One possible explanation from the political science literature on clientelism is that constituency service in an authoritarian regime is an institutionalized form of a patron-client re- 
lationship, where constituents obtain material benefits (e.g., waiver of a parking fine, or expedient processing of a public housing application) from the politician in exchange for political support. There are several reasons to reject such an interpretation, however. According to Stokes et al.'s $(2013,6-18)$ conceptual framework, clientelism refers to nonprogrammatic distribution that is conditional upon an individual's political support. In contrast, in Singapore's MPS, constituency service is nonconditional. PAP politicians are obliged to provide constituency service to anyone who turns up, regardless of their political affiliation. Indeed, under Singapore's transparent electoral process, votes remain secret. There is no way of discovering whether a particular constituent is a supporter or not. Furthermore, even if the PAP gains electoral credit if the appeal letter is successful at obtaining benefits for the constituent, the electoral credit is likely to amount to very little, particularly when we consider how its electoral impact is ambiguous in advanced liberal democracies.

To be sure, it would be a mistake to argue that the PAP is not motivated by reelection. After all, it has held regular elections ever since independence, and has strived very hard in numerous ways to convince voters that it is their best and correct choice on the ballot. The point, instead, is that the competitiveness of authoritarian elections is significantly less than democratic elections because autocrats often control the electoral institutions that govern the rules of elections. For example, Singapore's Election Department is located within the executive branch, allowing the PAP to freely manipulate electoral boundaries to its advantage (N. Tan and Grofman 2014). The PAP also has a supermajority in parliament, which allows it to manipulate electoral laws and the electoral system for its own benefit (N. Tan 2013). As a result, even if the PAP loses votes, it may not lose seats. Although the opposition won close to 40 percent of eligible votes in recent 2011 general elections, they won only 6.9 percent of the available seats. Finally, the country's media are also famously biased toward the PAP, resulting in a wary and frustrated opposition (George 2012). In sum, the odds of winning are almost always in favor of the incumbent regime rather than the opposition, even in the absence of blatant electoral fraud.

Because of all the institutional advantages that a ruling party has to win elections, it is particularly puzzling why its leaders would demand its rank-and-file politicians to conduct constituency service when there is so much less incentive to perform it. The rest of this article solves the puzzle by articulating the utility of the MPS as a complementary institution. 


\section{Episodic, Decaying, and Complementary Authoritarian Institutions}

In the past decade, political scientists have advanced our understanding of authoritarian regimes through conceptual innovation, conceptual clarification, and attention to the details of authoritarian institutions. A plethora of concepts has been invented to describe hybrid regimes such as electoral authoritarianism (Schedler 2002, 2006; Morse 2011), competitive authoritarianism (Levitsky and Way 2002, 2010; Bunce and Wolchik 2009), or hegemonic party autocracies (Magaloni 2006; Reuter and Gandhi 2011). The institutions that these hybrid regimes have, such as authoritarian elections and dominant ruling parties, work in a variety of ways to contribute toward authoritarian durability (see, for example, Boix and Svolik 2013; Slater 2010; Levitsky and Way 2010; Gandhi and Lust-Okar 2009; Brownlee 2007; Gandhi 2008; Magaloni 2006, 2008). From the perspective of contentious horizontal relationships among political elites, authoritarian institutions can help a regime to signal dominance to deter elite defection, coordinate elites into a protection pact, and have some sort of mechanism for resolving conflict among elites, among other functions. Alternatively, from the perspective of a hierarchical regime-population relationship, authoritarian institutions can help a dictator build mass loyalty, or help a dictator acquire information about mass opposition against the regime. In any case, be it support or opposition, a dictator can use his authoritarian institutions to respond flexibly to the demands and challenges of the masses.

Authoritarian elections, for example, are regulated by rules that are biased against opposition political parties and are advantageous for a ruling dominant party, resulting in an uneven playing field (Levitsky and Way 2010). Ruling dominant parties organize such biased elections because it is an opportunity for them to signal their dominance and to build mass support, among other functions (Magaloni 2006). When the ruling party obtains domineering and decisive electoral victories from the masses through the distribution of patronage, it deters elites within the party from defecting to the opposition and justifies the ruling party's continued manipulation of state resources. In addition, authoritarian elections may have an informational purpose in helping "regime incumbents identify their bases of support and opposition strongholds" (Gandhi and Lust-Okar 2009, 405). The regime may target its response more effectively in geographical terms if it observes falling vote share in particular electoral districts, or may be able to craft its responses more effectively in policy terms when it is articulated by opposition political parties during election rallies. Either way, the key idea is that the information gained 
through the raucous election process may prove to be particularly useful for the regime's elites to calibrate and target their responses most effectively and efficiently.

Dominant ruling parties can help co-opt elites, allow elites to resolve their conflicts, and work as a platform for elites to credibly share power and spoils (Svolik 2012; Brownlee 2007; Reuter and Remington 2009; Magaloni 2008). When the parties have a common standard of internal rules to share their spoils and resolve their conflict, elites are likely to stay within the ruling coalition to support the dictator rather than defect and challenge the regime. Yet, ruling parties are also vehicles for mass mobilization. At election time, party members often do the dirty work to fan out across the country to distribute patronage and campaign materials, hang banners, set up the logistics for local party rallies, mobilize the neighborhood to attend those rallies, and even talk to their neighbors to persuade them to vote for the ruling party. In ordinary times, local party members communicate and implement the regime's initiatives, and sometimes facilitate the upward flow of information to party leaders about the conditions of their local constituencies. Again, this allows the regime to potentially respond to a locality's demands or challenges.

While these authoritarian institutions function particularly well by themselves, they are not flawless. For instance, the episodic nature of authoritarian elections means that the various benefits obtained from organizing elections or having ruling parties are limited by the timing of their performance. If authoritarian elections represent an opportunity for the regime to distribute patronage or to acquire information about loyalty and opposition, then the tasks of patronage distribution and information gathering in the large gaps between elections demand explanation. We would expect regime incumbents to be at least as aware of the importance of both tasks in everyday situations as compared to such tasks during election periods. After all, a regime's opponents do not necessarily have the patience to wait for an election to come around before they choose to challenge the regime. Likewise, if understanding authoritarian ruling parties is so crucial to our analyses of how dictators share power with other elites and are vehicles for mass mobilization, then it is also equally important to understand concessions to co-opted elites and mass mobilization beyond episodic party meetings.

Notwithstanding the episodic nature of institutions under certain situations, moreover, institutions can also potentially decay over time. If institutions are rules of a game, then a decaying institution must imply that there is a gradual tendency of game players not to comply with the rules of the game. It suggests an initial high level of compliance by all game participants, but that more and more actors have incentives to de- 
viate from their best responses over time. A full explication of the origins and mechanisms of institutional erosion is beyond the scope of this article, but Kalyvas's (1999) account of the decay and breakdown of Communist parties in Eastern Europe serves as a useful description of the process. Members of political parties leave as they seek their fortunes elsewhere. Politicians and bureaucrats in periphery regions begin to assert their autonomy and no longer comply with instructions from the capital. Subordinates ignore orders from their superiors with no repercussions. China's experience with its decaying Communist party and state apparatus arguably erupted in the Tiananmen Square incident in 1989 , prompting the top leadership to implement tough policies to resist party decay (Shambaugh 2008). In short, institutions can potentially decay when more and more participants decide that they no longer wish to comply with its rules over time.

For dictators and their associated regimes, then, the twin flaws of episodic institutions and an institution's potential decay represent their worst nightmares. If the usefulness of institutions only kicks in when they are in play, autocrats will continue to remain nervous about the loyalty of their support and the challenges from their opponents whenever play is not in session. In addition, the ever-present fear of ruling party decay where ordinary party members leave the ruling party means that the effectiveness of mass mobilization is increasingly suspect. Not only is the ruling autocratic regime less effective in transmitting and implementing its policies in ordinary times, its capacity and ability to demonstrate domineering mass support during elections will likely decline precipitously over time. This can embolden opposition political parties to coordinate to challenge the ruling party to take advantage of its internal party decay.

One possible antidote to the nightmares of such flawed institutions is complementary institutions. As Hall and Soskice $(2001,17)$ write in describing the varieties of capitalism, "two institutions can be said to be complementary if the presence (or efficiency) of one increases returns from (or efficiency of) the other." In the same vein, Helmke and Levitsky $(2006,13-14)$ write about complementary informal institutions in Latin America by suggesting that "they are seen to enhance the efficiency or effectiveness of formal institutions." For authoritarian regimes, then, I argue that complementary institutions can plug the gaps in between episodic institutions and help forestall potential institutional decay, thereby enhancing and entrenching the overall institutional architecture of authoritarianism. Understanding and explaining how the everyday regularity of MPS in Singapore functions as a complementary institution contributes to our knowledge of authoritarian durability by drawing at- 
tention to institutional complementarities, beyond a narrow view that institutions exist uniquely by themselves (Hall and Soskice 2001, 17-21; Schneider 2013, 13-19). Careful attention to such complementarities demonstrates that complementary institutions can weave both substantive and symbolic functions that are vitally important for any authoritarian regime.

In Singapore, the ruling PAP demands that all its members of parliament conduct MPS on a weekly basis for at least three reasons - two substantive and one symbolic. First, it allows the ruling party to gain site-specific information about everyday grievances in the population so as to effectively target its response and to gain general information that it can utilize to formulate policies. Because the MPS is held on a regular weekly basis, it helps the PAP develop everyday social control by responding to the needs of the masses, thus being complementary to the episodic nature of authoritarian elections. Corroborating research on the importance of such everyday local responsiveness has been evident in Malaysia (Crouch 1996; Kuhonta 2011), Vietnam (Malesky and Schuler 2010), and China (Manion 1996; Tsai 2007; Dimitrov 2013; Meng, Pan, and Yang 2014; Truex 2014).

Second, the MPS is a mechanism for the PAP to recruit and socialize rank-and-file party members, thereby allowing the ruling party to forestall potential organizational decay. The weekly gathering of party members and volunteers to assist in the parliamentarians' conduct of MPS serves as a convenient platform for the PAP to consistently replenish its army of supporters (especially among youths) and to build organizational cohesion. Although the perils of authoritarian party decay have been well documented in Communist Eastern European countries (Kalyvas 1999) and in China (Shambaugh 2008), social scientists have not paid much attention to the technologies that ruling parties employ to attempt to forestall party decay. The complementary nature of the MPS lies precisely in its function to address the potential decay of the PAP as an institutionalized ruling party. Consequently, the observable implication of successful recruitment and socialization forestalling party decay is that ruling parties continue to exhibit strength and organizational cohesion over a long period of time, even when they encounter significant challenges to their rule. The long-term dominance of the PAP fits such a narrative. The counterfactual thought experiment is this: absent MPS, the PAP is much more likely to experience party decay - a scenario that is entirely plausible.

Third, the MPS is an everyday, material performance of the hegemonic ideology of elitism of the PAP. Skeptics of the role of hegemonic ideology in the maintenance of authoritarianism frequently point to the 
fact that bold claims, cheap talk, and noncredible promises and threats by authoritarian regimes are scarcely believable. This politics-as-performance analysis of the MPS highlights how hegemonic ideologies can be materially performed in order to render them credible. It is the lived material experiences of hegemonic authoritarianism that render hegemonic authoritarianism believable.

The rest of this article details a range of evidence that documents the historical evolution and contemporary purposes of the MPS.

\section{The Varied Utility of the MPS as a Complementary Institution}

Singapore's ruling PAP found its medication to the twin nightmares of episodic and potentially decaying institutions in the Meet-the-People Sessions, which were first created by Singapore's first chief minister David Marshall (K. Tan 2008, 295-301). In 1955, when Singapore held its first elections under limited self-government granted by the British colonial authorities, he had made the campaign promise that he "would dedicate a day in every week to receive the people of Singapore ... with or without appointment" (K. Tan 2008, 295) to potential voters in Cairnhill constituency. As leader of the Singapore Labor Front, David Marshall subsequently reiterated that promise when he formed a minority government and presented his cabinet under an old apple tree at Empress Place. The first MPS began in June 1955 in the air-conditioned press conference room of the Singapore Public Relations Office, and was held every Saturday morning (Comber 1994, 106). The aim, according to David Marshall, was to "break the frozen ground of Civil Service arrogance and to make our people understand that this was their government and officials were their servants" (Comber 1994, 106). Hence, David Marshall viewed the MPS as both an anticolonial and prodemocratic institution. Most remarkably, as Kevin Tan $(2008,298)$ discovered, members of the Singapore Labour Front who were elected into Singapore's first legislative assembly also began to conduct similar MPS in their respective constituencies on various days of the week, with all sessions following a fixed procedure. The PAP copied what the rest were doing, and has continued the practice to this day.

Gain Clear Information, Formulate Policies, and Target Response Recent political science research has suggested that locally embedded politicians in authoritarian regimes can be continually responsive to their constituents and therefore help to plug the large gaps in between elections. 
In Vietnam, locally nominated professional candidates ask more critical questions of the executive in publicly televised parliamentary debates (Malesky and Schuler 2010). In China, local government officials from temple groups or clan associations provide more and better public goods for their local constituencies (Tsai 2007). Furthermore, the autocrat's ability to gain information about grievances and target the response effectively is even more important when we consider the fact that authoritarian regimes are by definition authoritarian because they curtail the rights of the freedom of speech and the freedom of assembly of its citizens, as well as maintain control and censorship of the press. As King, Pan, and Roberts (2013) have demonstrated, in China the aim of such restrictions is to suppress the abilities of the masses to act collectively against the regime. Dictators need some other mechanism to circumvent their blunt tool of mass suppression to gain clear information about grievances within the population if they are concerned about mass collective action and revolt. To the extent that the MPS is institutionalized local embeddedness, there are three pathways by which the ruling PAP gains clear information about the masses, utilizes the information to formulate policies, and effectively targets its response to address grievances among Singaporeans.

First, the MPS allows for the intraparty aggregation of information among party members. This claim cannot be directly observed and verified due to the secretive nature of authoritarian ruling parties, but can be inferred through specific statements of elected parliamentarians and my interviews with party members. For the local members of parliament who have to meet more than thirty residents per week on a weekly basis throughout the entire year, it stands to reason that they will have a fairly good idea of what the most common grievances in their constituency are. More often than not, these parliamentarians find themselves evolving into social workers, advising residents about the details of a government's public policy, or directing the resident to alternative solutions other than relying on the government. In my interviews with PAP party members, the vast majority concur that their parliamentarians are at least in tune with the grievances of the residents, even if the level of actual empathy with the constituents' plights varies from one parliamentarian to another. For example, in a special report on the work of Malay members of parliament at their MPS, Berita Harian, Singapore's national Malay broadsheet, featured three Malay parliamentarians who noted the evolving demands of their constituents since the watershed general elections in 2011 and their challenges in meeting the residents' expectations (Mohd 2013). All of them were able to articulate the most pressing issues that their residents presented to them (public housing issues, financial aid, 
and immigration matters, in that order) as well as their efforts in resolving those issues.

In addition, local party activists who regularly volunteer their time and efforts at MPS also play a crucial role in intraparty information aggregation. According to my interviews with a PAP local branch party member, PAP party branch secretaries from all over the country meet at party headquarters to share important information about the problems and achievements of their local branches at least once a month. No further information was forthcoming beyond this piece of fact, but we can infer that at least some form of intraparty information aggregation and sharing takes place.

The second pathway through which the ruling PAP gains information and attempts to respond is through the bureaucracy. With eighty-seven members of parliament conducting their MPS every week receiving a conservative estimate of thirty cases, Singapore's government agencies receive, on average, 2,610 letters of appeal a week from all over the country. These appeal letters are distributed throughout government. Some find their way to the traffic police, many are sent to the Immigration and Checkpoints Authority, and most are sent to Singapore's public housing agency - the Housing and Development Board (HDB). It would be hard not to imagine the great amount of manpower and resources that are needed to respond to every specific case. In appeals that involve a bureaucrat's specific intervention into a matter, the waiting time for a reply can take as long as a month from the relevant government agency. For cases that involve clear rejections against the appeal, a rejection can vary from a simple standard form letter from the traffic police to a lengthy letter from the HDB explaining the justification for rejecting one's appeal. Whatever the case, the resident at least knows which government agency to blame, and when to return to the parliamentarian for another appeal letter.

A recent example demonstrates how repeated MPS appeal letters to government agencies on particular matters can sometimes lead to policy changes. In Prime Minister Lee Hsien Loong's annual National Day Rally Speech in 2014, he went to great efforts to explain to Singaporeans how the government was changing policies to ensure that elderly citizens can have a comfortable retirement. The prime minister took on the role of an imaginary financial adviser and described how a hypothetical elderly "Mr. Tan" was prevented from benefiting from an HDB policy known as a lease buyback scheme because Mr. Tan did not meet the scheme's requirements. The prime minister continued the story by narrating in colloquial Singapore English, 
So, Mr. Tan says, "Oh, what a pity. Can I see my MP [member of parliament] or not to appeal for a lease buyback?" So, I told him, "Sure, your MP, I think this is Lee Hsien Loong, Block 322 Avenue 3, and every Wednesday night at $8.00 \mathrm{pm}$." And that is how my advisory session ended and next thing I knew, I saw Mr. Tan at my MPS. . . . So HDB has studied this carefully and I am happy to tell you, as well as Mr. and Mrs. Tan if they are still watching that we will extend the lease buyback scheme." (Lee 2014)

When PAP parliamentarians find that their attempts to resolve the complaints of their residents hit a brick wall because of the intransigence of government agencies, then they often vent their frustrations by raising anecdotes from their MPS in their parliamentary speeches. This constitutes the third and final pathway through which the party leaders and the bureaucracy gain general information they can use to develop public policies that specifically address the concerns of the citizenry. As of November 10, 2014, there were 436 mentions of the exact phrase "Meet-the-People" in Singapore's parliamentary debates since $1955 .{ }^{6}$ While this amounts to slightly more than a paltry seven times every year, it is significant enough to the extent that the Singapore parliament only meets on average once a month beyond the busy February budget period.

The first noteworthy mention of the MPS in parliament was on November 7, 1955, when parliament held a debate on the Road Traffic (Amendment) Bill. Then Minister for Communications and Works Francis Thomas, in support of the bill, noted that Chief Minister David Marshall had, at his very first MPS, "received a complaint or request from a young person who was licensed to drive elsewhere but was restricted in Singapore" ("Singapore Parliament Reports" 1955). Hence there was a need for parliament to harmonize its traffic regulations with the United Kingdom and Singapore. In a sign that MPS was getting increasingly important and worrisome for the PAP's parliamentarians after independence, Bukit Ho Swee's member of parliament Seah Mui Kok, in a 1968 speech about granting Singapore citizenship for the working class in the newly born nation, lamented that "We are getting a lot of trouble and headaches from our constituents during the 'Meet-the-People' sessions on this matter. I think even a large amount of aspro and aspirin will not cure our headaches" ("Singapore Parliament Reports" 1968). After noting how the bureaucracy was unresponsive to the appeal letters of parliamentarians, he went on to warn, "I think the Government must be very realistic on this issue. They must be aware that all Members of Parliament should not be made to look stupid in the eyes of the public." More re- 
cently, in the 2013 budget debates concerning the Ministry of National Development, Lee Bee Wah, Teo Ho Pin, and Muhamad Faisal bin Abdul Manap all raised specific examples from their respective MPS to urge the Ministry of National Development to reconsider its policies on resale levies for public housing and rental flats ("Singapore Parliament Reports" 2013). In response to the barrage of criticisms and questions in parliament with regard to skyrocketing public housing prices, Singapore's public housing agency - the HDB - initiated more policy changes to "cool down" and stabilize the market in addition to ones they had already initiated (Ho 2013; IRAS 2013).

Through these three pathways, then, the ruling PAP has a locally embedded everyday platform to gain information about grievances and opposition within the population and target its response to the masses as well as the individual, thus transcending the tight limits of episodic elections. The dictator can sleep slightly more soundly, knowing that the most desperate grievances are attended to, or that he is at least seen to be attending to them. Come election time, he will at least have some level of confidence that he knows what the most pressing issues are and respond to them effectively, even when he has broadly curtailed the freedom of speech of his citizens.

\section{Recruiting and Socializing Party Members to Forestall Potential Party Decay}

More often than not, political scientists have attempted to analyze political parties through relatively easy-to-observe measures such as votes, speeches, manifestos, or surveys. Scholarly research on the internal workings of political parties is often a rare gem (see, for example, Askew 2008; Krauss and Pekkanen 2011). If dominant ruling parties wish to preserve their regimes, then managing the difficult-to-observe internal dynamics of the party is ostensibly one of their top priorities. The MPS, thus, enters the picture as a platform for the everyday recruitment and socialization of ordinary party members.

Within every MPS, the entire array of people who assist the member of parliament are known as volunteers. Each MPS has a similar set of duties that MPS volunteers have to fulfill. Overall, a typical team on a typical day of an MPS conducted by the ruling PAP is made up of about fifteen active volunteers: there are two receptionists giving out queue numbers, there are anywhere from three to six case writers at any one time recording cases, the MP may have anywhere from one to three personal assistants, there are anywhere from three to six letter writers, and there are two logistics personnel. In some MPS, case writers record their 
cases on laptops into a proprietary database, which then automatically generates formatted case sheets for easy reading, or which the parliamentarian or his assistants can use to retrieve and edit the soft copy case sheet when speaking to the resident. In other MPS, case writers record their cases on pieces of paper, which are then passed to the parliamentarian and then to the letter writer. Whether an MPS uses more or less technology is entirely up to the preference of the presiding parliamentarian and the technical expertise of his or her group of volunteers.

This fact in turn speaks to the organization and hierarchy of the people conducting the MPS. In my interviews with volunteers, it appears that each MPS functions as an autonomous cell group that is helmed by the parliamentarian in charge of the electoral district, distinct and separate from other MPS volunteer groups. ${ }^{7}$ Little technical expertise sharing takes place across MPS from different districts and different constituencies. While the local member of parliament may preside over the conduct of the MPS, meet residents, and sign off on every letter, local PAP party branch leaders are the ones who actually resolve logistical and case issues during the actual conduct of the MPS. In these mini-leadership roles, experienced local PAP party branch leaders can perform a wide variety of overarching functions such as dictate and direct what advice is given to residents with troublesome problems even before they meet the parliamentarian, calm down rowdy residents who vent their anger at the case writers, give advice on the particular wording of certain letters, and pair inexperienced volunteers with experienced ones, among others.

The local PAP party branch leaders mentioned above are typically the local branch secretary and assistant branch secretary, who are assisted by a treasurer and deputy treasurer, thus forming a branch committee. The local PAP parliamentarian is the branch chairman. There are also the Young PAP chairman and vice chairman for each branch, who are represented or who may hold concurrent roles on the branch committee. The entire local branch committee of the PAP thus forms the core group of regular volunteers at every MPS. Because this core team meets on a weekly basis at a specific time and location, they form very close personal relationships with each other. Beyond their work in the local PAP branch committee and regular MPS, many of them forge strong friendships with common interests.

Outside this core group are ad hoc volunteers from other grassroots organizations such as the People's Association (PA), often comprising not more than half of the total volunteers. The PA is a government statutory board that is entrusted to organize grassroots activities and publicize government initiatives. The board of the PA is chaired by Prime 
Minister Lee Hsien Loong himself and is populated with various PAP cabinet ministers, PAP parliamentarians, and progovernment civil society activists. Under the PA's Young Executive Committee (YEC) scheme, young residents come together to organize grassroots events for their community such as fun walks, movie screenings, sports festivals, and festival celebrations. There are also other organizations under the broad umbrella of the PA like the Community Centre Management Committees (CCMCs), Citizens' Consultative Committees (CCCs), Residents' Committees (RCs), and the Neighborhood Committees (NCs) (Tan and Tan 2003). Because the PAP and the PA are so tightly knit, many of the young members of these committees often find themselves being invited to volunteer to "serve the residents" at these weekly MPS, if they are not already PAP party members themselves.

In addition, young volunteers from local schools are also recruited to participate in the MPS. At Hwa Chong Institution, one of the top junior colleges in Singapore, their brightest students are encouraged to join the Grassroots Attachment Programme (GAP), which often entails the students' shadowing certain prominent members of parliament, which primarily means helping out at the MPS of their assigned parliamentarian. At Raffles Institution, the other top junior college in Singapore, the program is called the Political Leaders' Attachment Programme (PLAP). Such programs not only expose high-achieving students to the practice of politics and socialize them into the world of political service, they are also a heuristic mark of social compassion that these students note on their list of achievements when they apply for government scholarships. Even professional lawyers find themselves volunteering their time at MPS in order to fulfill the pro bono hours requirement recommended by their individual law firms.

Not only is there socialization of ordinary party members and nonparty volunteers through the "serving the residents" work that is done during the MPS itself, additional socialization often takes place after MPS into the wee hours of the night. Late-night suppers after MPS are often pensive moments when elite PAP politicians forge close relationships with their ordinary party members through food and small talk. The parliamentarian will also celebrate special occasions such as Mother's Day, Father's Day, or Chinese New Year with cakes and meals, often, but not always, sponsored by the parliamentarian himself.

As Barr (2012) has noted, it is quite inconceivable for some of the PAP's elites to defect to another political party. In parallel, one also rarely hears of ordinary PAP party members quitting the PAP to defect to an opposition party, no matter how much frustration they may have with 
the party. The consistent everyday flow of socialization that the MPS allows is one reason why ordinary PAP party members are constantly kept in contact with one another, thereby helping the party forestall potential institutional decay. From this perspective, the weekly MPS is akin to attending a weekly religious service. One's weekly attendance at church or at the mosque means that it is easy to make friends and share in the happiness of devotion and service. However, it also means quitting the religion is much harder than it appears.

\section{Performing Hegemonic Ideology}

Politics is often substantive and symbolic at the same time. Authoritarian regimes are not only interested in achieving substantive outcomes but they are also interested in generating symbolic hegemony. Toward that end, dictators often create public spectacles to publicly demonstrate their dominance and engage in a material performance of ideology (Wedeen 1999). After all, cheap talk counts for little. As Magaloni (2006, 15) argues, material displays of dominance "generate an image of invincibility in order to discourage party splits," and allow ruling parties to "control institutional change to their advantage."

In Singapore, notwithstanding the important substantive implications of MPS for responding to local grievances and for ruling party cohesion, the entire process of meeting the people, helping the people, and writing appeal letters for the people also certainly qualifies for excellent political symbolism. Indeed, even the infamously blunt Lee Kuan Yew himself thought that local politics was completely about public relations. In 1976, J. F. Conceicao charged in parliament that government bureaucrats were showing discourtesy to the public and "ignoring the sensitivities and needs of the very people he is supposed to be doing the job for" ("Singapore Parliament Reports" 1976). His recommendation was that senior officers in the civil service sit with members of parliament at their MPS in order "to come and see for themselves how people at the grassroots feel." In response, Lee Kuan Yew said that Conceicao should reconsider his recommendation because "a civil servant who can both do his job as an administrator and be good at the public relations side of it ... would have learnt the secret of politics and will [compromise] the Government." Instead, the job of a Singaporean member of parliament at his MPS was "to keep his constituents happy whilst having to say 'No' to them in the politest of terms."

As many scholars have highlighted, the PAP's ideological stranglehold over the governance of Singapore contains at least three strains of thought—elitism, meritocracy, and pragmatism (Chua 1985; Rodan and 
Jayasuriya 2007; Tan 2008; Barr and Skrbiš 2009). Singapore should be administered by a group of technocratic elites that is meritocratically selected, governing the country with a pragmatic sense of doing whatever it takes to get the job done. "Governance that works" is the mantra (Kausikan 1997). Yet, these ideas are not flawless. The principles of elitism and meritocracy risk undermining themselves when inequality rises, and when the government is perceived to be out of touch with the common man (Tan 2008). Pragmatism exacerbates disappointment among the masses when the government appears to be cold and calculating. As the Singaporean writer Catherine Lim famously noted in her opinion piece titled "The PAP and the People-A Great Affective Divide" in the Straits Times in 1994, the PAP leaders have "intelligence, single-mindedness, sternness of purpose and cool detachment" coupled with an "impersonal, brisk, business-like, no-nonsense, pre-emptive" style (Lim 1994).

Less studied is how the PAP attempts to take the edge off such a cold, calculating image, which nonetheless supports the continuation of elitism. While true empathy varies from one individual parliamentarian to another, the very act of "serving the residents" through meeting the residents and signing their appeal letters is materialized in the performance of the MPS. In all the interviews that I have done with volunteers involved in the MPS, everyone uniformly emphasizes the "help" that they are rendering to the constituents. MPS volunteers are specifically called volunteers precisely because they believe it to be a form of charitable community service where people volunteer their time and effort to help the disadvantaged in the community. In this sense, then, the parliamentarian and his volunteers must necessarily be in a relatively better position to extend help to the disadvantaged. Everyday elitism and power asymmetry are entrenched when residents stand in line to wait their turn, complain to the parliamentarian about their problems, and when the parliamentarian signs appeal letters on their behalf. It is not as if the residents cannot write appeal letters for themselves. But the parliamentarian's letter is perceived to be more effective for appealing to the authorities and is more likely to succeed simply because of his imagined higher status.

The perception of power asymmetry grows when the parliamentarian is a cabinet minister, and grows even further when he is deemed to be a "powerful" cabinet minister like the prime minister or deputy prime minister. The number of cases that individual parliamentarians receive each week demonstrates this. By most accounts from my interviews and the Berita Harian newspaper report (Mohd 2013), ordinary members of parliament receive, on average, about thirty to fifty cases per week, with 
the vast majority coming from their own district. Ministerial-level members of parliament receive more than double that amount. Law and Foreign Affairs Minister K. Shanmugam deals with about 100 to 120 residents every week. ${ }^{8}$ The prime minister, as mentioned, receives a similar amount, writing about 110 letters a week, with just under half of all cases from his own district of Teck Ghee and the rest from other districts in the Ang Mo Kio Group Representative Constituency.

Another significant episode also demonstrates this growth in power asymmetry between a cabinet minister and the ordinary citizenry. In late 2012, speaker of parliament and parliamentarian for Punggol East Michael Palmer resigned from the PAP and from the legislature after confessing that he had committed adultery with a PA grassroots volunteer. At the same press conference at which Michael Palmer announced his resignation, Deputy Prime Minister Teo Chee Hean, ostensibly entrusted with managing the by-election campaign to elect a new parliamentarian for Punggol East, declared three times in English, once in Malay, and once in Chinese that residents of Punggol East will be "taken care of" and "continue to be looked after" (TODAYdigital 2012). As a demonstration of "taking care of" the residents, Deputy Prime Minister Teo noted that he would replace Michael Palmer for his MPS on Monday, and that Minister of State for Trade and Industry Teo Ser Luck would hold replacement MPS every Tuesday until a new parliamentarian was elected (Spykerman 2012). At the first MPS presided by Deputy Prime Minister Teo, reporters noted that fifty residents had queued up to meet with Teo, even before the session began (Hussain 2012). When a reporter asked a resident why he turned up, the resident replied that Deputy Prime Minister Teo "has weight."

Finally, not only is the conduct of the MPS itself a material performance of the hegemonic ideology of elitism, a peculiar variation that is interesting to highlight is that the MPS conducted by the PAP and by opposition parties are held at distinctly different venues. The PAP MPS are typically conducted at PAP kindergarten centers dotted throughout the island or at offices of the local Residents' Committees, whereas opposition party MPS are typically conducted at the empty spaces at the ground floors of public housing estates, locally known as void decks. In the PAP kindergarten centers or Residents' Committee centers, residents get to wait in air-conditioned comfort, have access to a washroom, and stare at PAP party posters plastered on the walls of a permanently built office space. At the open void decks where opposition party parliamentarians conduct their MPS utilizing flimsy makeshift tables and mobile partition walls, residents have no access to a washroom and have to spend their time waiting in Singapore's hot and humid climate. No room is left 
to the imagination about which party has the better resources and therefore which can provide better material comfort for Singaporeans.

In order to understand how such an arrangement came about, one needs to look back to the 1991 general election. Before 1991, political opposition in parliament in postindependence Singapore was limited to Joshua Benjamin Jeyaretnam's solitary by-election win in Anson in 1981 and his follow-up win alongside Chiam See Tong in Potong Pasir in the 1984 general election. That makes only two elected opposition parliamentarians since independence in 1965. However, in 1991, an unprecedented four opposition party candidates were elected in the general election that year. They were Chiam See Tong, Low Thia Khiang, Lim How Doong, and Cheo Chai Chen. Until 1991, all parliamentarians had their individual offices built physically at the specific void deck of a local HDB block within their constituency. All their MPS were held within those offices. However, after the 1991 general elections held in August, the HDB announced in November that all members of parliament, both from the PAP and the opposition, were no longer allowed to build their offices at void decks and must find alternative arrangements before September 1992 (Straits Times 1991). Subsequently, applications by the new opposition parliamentarians to build offices were summarily rejected, and the PAP parliamentarians began arrangements to shift their MPS to the PAP-run kindergartens within the constituency instead. Eventually, the opposition worked out an arrangement with the HDB whereby they could only erect temporary structures in void decks for their MPS but not construct permanent offices.

The everyday material performance of elitism helps the PAP publicly display its dominance beyond the limitations of episodic elections. It no longer has to wait till elections to fan out over the country to distribute goodies or paint the country in party colors. The PAP, moreover, neither relies blatantly on cheap talk in the controlled press nor engages in meaningless spectacles. Materialized and meaningful performance displays elite dominance and entrenches hegemony that is both real and imagined.

\section{Conclusion}

Our understanding of the durability of authoritarian and hybrid regimes has improved tremendously over the past few years. We now have answers to a wide variety of questions such as why biased authoritarian elections are held and how they work, why some dominant ruling parties are more coherent than others, why some Communist regimes have collapsed whereas others have survived. These theoretical and empirical ad- 
vancements have been made with an exclusive focus on authoritarian institutions, opening the doors to other questions that have remained unresolved. As a first step toward addressing the problems of episodic and potentially decaying authoritarian institutions, I offer the answer of authoritarian complementary institutions.

This overarching framework of authoritarian complementary institutions has theoretical, empirical, and normative implications for our study of authoritarian regimes, particularly those governed by dominant ruling parties. First, existing scholarly work overemphasizes the theoretical and empirical importance of ostensibly visible but episodic institutions such as parties, parliaments, and elections, neglecting the less visible everyday machineries of authoritarian regimes (see Pepinsky 2014, 19-21). In particular, researchers have not quite resolved two important issues. In the first instance, scholars have left unidentified the mechanisms through which authoritarian regimes attempt to acquire everyday information about their own supporters and the opposition in their self-created low-information environments, and how they use the information to pursue various ends. Conventional methods such as spies and secret police alongside more contemporary approaches such as social media monitoring are useful but often imperfect tools for keeping tabs on citizens. While Peter Lorentzen (2013) has argued that autocrats sometimes allow for "small-scale, narrowly economic protests" to gain information about mass grievances within the population, it remains unclear how valuable the information is from such small protests, how autocrats distinguish ex ante between tolerable and nontolerable protests, and how autocrats can manage such protests to ensure that they do not provoke more collective action rather than less.

A second mechanism that the existing literature has left ambiguous is how dominant ruling parties recruit and socialize ordinary party members for the continued maintenance of the party organization. After all, political parties are not merely exclusive clubs of ruling elites but often require ordinary party members to do the dirty work. These ordinary party members may well be motivated by material rewards from being a party member. But if rewards are minimal or irregular, then how and why ordinary party members become involved in devoting time and effort toward dirty work are questions that remain unanswered. Scholars of authoritarianism, then, need to look theoretically and empirically beyond the ostensible functions of easily visible authoritarian institutions, and be sensitive to the everyday demands of authoritarianism.

Furthermore, the findings in this article speak to the issue of institutional change. Current scholarship on authoritarian institutions typically 
sees those institutions as originating in response to particular problems at the beginning of authoritarianism. But this may not always be true. Dominant mass political parties are often born as anticolonial independence movements that initially operated in a democratic fashion. Few studies have examined how originally democratic institutions evolve dynamically over time to acquire authoritarian features. As the careful reader will realize, the roots of the MPS were democratic, and it evolved over time to fulfill the three tasks for the PAP. The particular mode of institutional change can be classified under what Mahoney and Thelen (2010, 17-18) term "institutional conversion," where institutions "remain formally the same but are interpreted and enacted ... to new goals, functions, or purposes." More specifically, institutional conversion occurs when "existing institutions are adapted to serve new goals or fit the interests of new actors" (Streeck and Thelen 2005, 26). Similarly, the authoritarian PAP saw fit to adapt the originally democratic MPS and continue with its regular performance over sixty years to fit its own authoritarian purposes. It was also at specific points in time, particularly in 1991, when the PAP made subtle changes to the MPS to reveal and reassert the MPS's importance for marginalizing political opponents. The theoretical and empirical lesson for researchers, therefore, is that we cannot assume the functionalist origins of institutions, even as we find functionalist explanations of them.

Finally, the paradox of responsiveness to citizen demands in authoritarian regimes forces us to reconsider the normative implications of authoritarian regimes themselves. For a long time, most scholars have largely assumed the simple dichotomy: authoritarianism bad, democracy good. ${ }^{9}$ Such a perspective is particularly prominent in the subfield of the political economy of development. Prominent development economist William Easterly railed against authoritarian regimes in his most recent book, calling the notion of authoritarian development "the moral tragedy of development today" (Easterly 2013, 6). Acemoglu and Robinson (2012) have famously argued that rich countries are rich precisely because of their inclusive (read: democratic) political institutions, whereas poor countries are poor because of their extractive (read: authoritarian) political institutions. Yet, there are arguably some lessons to be learned from ostensibly benign authoritarian responsiveness that has been highlighted in this study and other recent work. In China, He and Warren (2011) have suggested that a positive deliberative political culture can be sustained even within the margins of an authoritarian regime. In Vietnam, Malesky, Abrami, and Zheng (2011) found that a critical and deliberative parliament has resulted in more equitable development as 
compared to China. In Malaysia, the government was motivated to pursue equitable development when prompted by intercommunal violence (Kuhonta 2011). Are benign authoritarian regimes that generate equitable economic development minimally tolerable or respectable (Sagar 2014)? Are liberal democracies that are ironically nonresponsive and politically unstable necessarily good? These are vexing normative questions that all scholars, especially political philosophers, will have to wrestle with.

Although none of the arguments made in this article imply that authoritarian complementary institutions are either necessary or sufficient for authoritarian durability, what the arguments do suggest is that an authoritarian regime can become extraordinarily resilient to democratization if its matrix of institutional complementarities functions well. A dictator can still live and rule even if he suffers from nightmares, but a dictator who can find the correct medication for his persistent ailment can surely sleep more soundly at night. For such late-democratizing authoritarian regimes, then, the bar for democratization has been raised significantly. New analytical frameworks will be needed to study the modes and prospects of democratization for such regimes.

Elvin Ong is a PhD graduate student in the Department of Political Science at Emory University. He received his MPhil in Politics (Comparative Government) from St. Antony's College, University of Oxford. His research focuses on the authoritarian regimes and political economy of development in East and Southeast Asia. His coauthored article "Singapore's 2011 General Elections and Beyond: Beating the PAP at Their Own Game" has been published in Asian Survey.

\section{Notes}

Earlier versions of this article were presented at the Canadian Council of Southeast Asian Studies 2013 Conference, at the Association for Asian Studies 2014 Annual Conference, and at the ENITAS 2014 Scholarship Presentation. I thank the participants at the conferences for their feedback; the Institute of Thai Studies at Chulalongkorn University for the ENITAS Scholarship; the AAS Malaysia, Singapore, Brunei Studies Group for the Ronald Provencher Travel Award and the John A. Lent Prize; as well as Richard Doner, Jennifer Gandhi, Tom Clark, Clara Boulianne Lagace, the JEAS editor, and the two anonymous reviewers for their very helpful comments. I am particularly grateful to Bernard Chen for our countless conversations that inspired this article.

1. See Lijphart (1971) as well as Seawright and Gerring (2008) for the definition and the potential theoretical contributions of deviant cases.

2. For an official view of MPS, see the public relations video produced by the PAP branch in Chong Pang, the district helmed by Minister for Foreign 
Affairs and Law K. Shanmugam (Sights of Singapore: Chong Pang Meet the People Se 2014). For a more candid view, see the interview of Brigadier-General Tan Chuan Jin, a newly elected parliamentarian in the Kampong Ubi-Kembangan-Chai Chee district in Marine Parade Group Representative Constituency ("Tan Chuan-Jin's First Meet-the-People Session," 2013).

3. Lee Hsien Loong's Facebook status update on January 17, 2013.

4. I thank the JEAS editor for this particular insight.

5. Lee Hsien Loong's Facebook photo upload on April 22, 2013, at https://www.facebook.com/leehsienloong/photos/a.344710778924968.83425.12 $5845680811480 / 696910887038287 /$ ?type $=1$ (accessed November 10, 2014). 2014.

6. Author's count of Singapore's Parliament Reports as of November 10,

7. In the multimember group representative constituencies (GRCs) of Singapore, voters vote for a group of candidates under different party labels. The group of candidates who win the majority of votes in first-past-the-post elections wins the entire GRC. Subsequently, for the purposes of conducting the MPS, each GRC is split up into different districts. Otherwise, single-member constituencies (SMCs) are counted as an electoral district on their own. For a clear exposition of Singapore's parliamentary rules and election to parliament, see Tan (2014).

8. Watch from 0:38 ("Sights of Singapore: Chong Pang Meet the People Se," 2014).

9. For an exception, see Fukuyama (2013). I thank the JEAS editor for alerting me to the nuances of that article.

\section{References}

Acemoglu, Daron, and James A. Robinson. 2012. Why Nations Fail: The Origins of Power, Prosperity, and Poverty. New York: Crown Publishers.

Askew, Marc. 2008. Performing Political Identity: The Democrat Party in Southern Thailand. Chiang Mai, Thailand: Silkworm Books.

Barr, Michael. 2012. "Splits in the Singapore Elite." New Mandala. November 2. http://asiapacific .anu .edu .au/newmandala/2012/11/02/splits-in-thesingapore-elite (accessed May 21, 2015).

Barr, Michael D., and Zlatko Skrbiš. 2009. Constructing Singapore: Elitism, Ethnicity and the Nation-Building Project. Copenhagen: NIAS Press.

Boix, Carles, and Milan W. Svolik. 2013. "The Foundations of Limited Authoritarian Government: Institutions, Commitment, and Power-Sharing in Dictatorships." Journal of Politics 75, 2: 300-316.

Brancati, Dawn. 2014. "Democratic Authoritarianism: Origins and Effects." Annual Review of Political Science 17, 1: 313-326.

Brownlee, Jason. 2007. Authoritarianism in an Age of Democratization. New York: Cambridge University Press.

Bunce, Valerie J., and Sharon L. Wolchik. 2009. "Defeating Dictators: Electoral Change and Stability in Competitive Authoritarian Regimes." World Politics 62, 1: 43-86.

Cain, Bruce E., John A. Ferejohn, and Morris P. Fiorina. 1984. "The Constituency Service Basis of the Personal Vote for U.S. Representatives and 
British Members of Parliament.” American Political Science Review 78, 1 : 110-125.

Chan, Heng Chee. 1976. "The Role of Parliamentary Politicians in Singapore." Legislative Studies Quarterly 1, 3: 423-441.

Chua, Beng Huat. 1985. "Pragmatism of the People's Action Party Government in Singapore: A Critical Assessment." Southeast Asian Journal of Social Science 13, 2: 343-354.

- - . 2003. "Multiculturalism in Singapore: An Instrument of Social Control." Race and Class 44, 3: 58-77.

Comber, Leon. 1994. "David Marshall and 'Meet the People'-Singapore 1955-56." Asian Studies Review 18, 2: 105-112.

Crouch, Harold A. 1996. Government and Society in Malaysia. Ithaca, NY: Cornell University Press.

Diamond, Larry. 2012. “The Coming Wave.” Journal of Democracy 23, 1: 5-13.

Dimitrov, Martin K. 2013. "Vertical Accountability in Communist Regimes: The Role of Citizen Complaints in Bulgaria and China." In Why Communism Did Not Collapse: Understanding Authoritarian Regime Resilience in Asia and Europe, ed. Martin K. Dimitrov, 276-302. New York: Cambridge University Press.

Dropp, Kyle, and Zachary Peskowitz. 2012. "Electoral Security and the Provision of Constituency Service." Journal of Politics 74, 1: 220-234.

Easterly, William. 2013. The Tyranny of Experts: Economists, Dictators, and the Forgotten Rights of the Poor. New York: Basic Books.

Fenno, Richard. 1978. Home Style: House Members in Their Districts. Boston: Little, Brown and Company.

Fiorina, Morris P. 1977. "The Case of the Vanishing Marginals: The Bureaucracy Did It." American Political Science Review 71, 1: 177-181.

Fukuyama, Francis. 2013. "What Is Governance?" Governance 26, 3: 347-368.

Gandhi, Jennifer. 2008. Political Institutions Under Dictatorship. New York: Cambridge University Press.

Gandhi, Jennifer, and Ellen Lust-Okar. 2009. "Elections Under Authoritarianism." Annual Review of Political Science 12, 1: 403-422.

George, Cherian. 2007. "Consolidating Authoritarian Rule: Calibrated Coercion in Singapore." Pacific Review 20, 2: 127-145.

- - 2012. Freedom from the Press: Journalism and State Power in Singapore. Singapore: NUS Press.

Hall, Peter A., and David W. Soskice, eds. 2001. Varieties of Capitalism: The Institutional Foundations of Comparative Advantage. Oxford: Oxford University Press.

He, Baogang, and Mark E. Warren. 2011. "Authoritarian Deliberation: The Deliberative Turn in Chinese Political Development." Perspectives on Politics 9, 2: 269-289.

Heitshusen, Valerie, Garry Young, and David M. Wood. 2005. "Electoral Context and MP Constituency Focus in Australia, Canada, Ireland, New Zealand, and the United Kingdom." American Journal of Political Science 49, 1: 32-45. 
Helmke, Gretchen, and Steven Levitsky. 2006. Informal Institutions and Democracy: Lessons from Latin America. Baltimore: Johns Hopkins University Press.

Ho, Paul. 2013. "New HDB Rules Create Anomaly - Cannot Buy HDB but Can Finance Condo?" Yahoo News Singapore. September 2. http://sg.news .yahoo.com/hdb-rules-create-anomaly-cannot-buy-hdb-finance 113651136.html (accessed May 21, 2015).

Hussain, Amir. 2012. "Big Turn-Out at Punggol East Meet-the-People Session." TODAY. December 18. www.channelnewsasia.com/news/specialreports /parliament/news/big-turn-out-at-punggol-east-meet-the-peoplesession/530532.html (accessed May 21, 2015).

IRAS. 2013. "Additional Measures to Ensure a Stable and Sustainable Property Market." Inland Revenue Authority of Singapore. January 11. www.iras .gov.sg/irasHome/page03a.aspx?id=14342 (accessed May 21, 2015).

Johannes, John R., and John C. McAdams. 1981. "The Congressional Incumbency Effect: Is It Casework, Policy Compatibility, or Something Else? An Examination of the 1978 Election." American Journal of Political Science 25, 3: 512-542.

Kalyvas, Stathis N. 1999. "The Decay and Breakdown of Communist One-Party Systems." Annual Review of Political Science 2, 1: 323-343.

Kausikan, Bilahari. 1997. "Governance That Works." Journal of Democracy 8, 2: 24-34.

King, Gary, Jennifer Pan, and Margaret E. Roberts. 2013. "How Censorship in China Allows Government Criticism but Silences Collective Expression." American Political Science Review 107, 2: 326-343.

Krauss, Ellis S., and Robert Pekkanen. 2011. The Rise and Fall of Japan's LDP: Political Party Organizations as Historical Institutions. Ithaca, NY: Cornell University Press.

Kuhonta, Erik Martinez. 2011. The Institutional Imperative: The Politics of Equitable Development in Southeast Asia. Stanford: Stanford University Press.

Lee, Hsien Loong. 2014. "Prime Minister Lee Hsien Loong's National Day Rally 2014 (Speech in English)." August 17. www.pmo.gov.sg /mediacentre/prime-minister-lee-hsien-loongs-national-day-rally-2014speech-english (accessed May 21, 2015).

Levitsky, Steven, and Lucan A. Way. 2002. "The Rise of Competitive Authoritarianism." Journal of Democracy 13, 2: 51-65.

- - . 2010. Competitive Authoritarianism: Hybrid Regimes After the Cold War. New York: Cambridge University Press.

Lijphart, Arend. 1971. "Comparative Politics and the Comparative Method." American Political Science Review 65, 3: 682-693.

Lim, Catherine. 1994. "The PAP and the People-A Great Affective Divide." Straits Times. September 3. http://catherinelim.sg/1994/09/03/the-pap-andthe-people-a-great-affective-divide (accessed May 21, 2015).

Lorentzen, Peter L. 2013. "Regularizing Rioting: Permitting Public Protest in an Authoritarian Regime." Quarterly Journal of Political Science 8, 2: 127-158. 
Magaloni, Beatriz. 2006. Voting for Autocracy: Hegemonic Party Survival and Its Demise in Mexico. New York: Cambridge University Press.

- - . 2008. "Credible Power-Sharing and the Longevity of Authoritarian Rule." Comparative Political Studies 41, 4-5: 715-741.

Mahoney, James, and Kathleen Thelen. 2010. Explaining Institutional Change: Ambiguity, Agency, and Power. Cambridge: Cambridge University Press.

Malesky, Edmund, Regina Abrami, and Yu Zheng. 2011. "Institutions and Inequality in Single-Party Regimes: A Comparative Analysis of Vietnam and China." Comparative Politics 43, 4: 409-427.

Malesky, Edmund, and Paul Schuler. 2010. "Nodding or Needling: Analyzing Delegate Responsiveness in an Authoritarian Parliament." American Political Science Review 104, 3: 482-502.

Manion, Melanie. 1996. "The Electoral Connection in the Chinese Countryside." American Political Science Review 90, 4: 736-748.

Meng, Tianguang, Jennifer Pan, and Ping Yang. 2014. "Conditional Receptivity to Citizen Participation Evidence from a Survey Experiment in China." Comparative Political Studies (December): 1-35. doi: $10.1177 / 0010414014556212$.

Mohd, Azahar. 2013. "Kami Mendengar Keprihatinan, Lakukan Yang Terbaik." Berita Harian, April 15.

Morse, Yonatan L. 2011. "The Era of Electoral Authoritarianism." World Politics 64, 1: 161-198.

Mu, Fa Rong. 2008. "Lee Xian Long: De Bu Dao Min Xin, Jiu De Bu Dao Xuan Piao." Nan Fang, Zha Zhi. June 24. http://admin.nfyk.com/ztbd /ShowArticle.asp?ArticleID=978 (accessed May 21, 2015).

Parker, Glenn R., and Roger H. Davidson. 1979. "Why Do Americans Love Their Congressmen So Much More Than Their Congress?" Legislative Studies Quarterly 4, 1: 53-61.

Pepinsky, Thomas. 2014. "The Institutional Turn in Comparative Authoritarianism." British Journal of Political Science 44, 3: 631-653.

Rajah, Jothie. 2012. Authoritarian Rule of Law: Legislation, Discourse and Legitimacy in Singapore. New York: Cambridge University Press.

Reuter, Ora John, and Jennifer Gandhi. 2011. "Economic Performance and Elite Defection from Hegemonic Parties." British Journal of Political Science 41, 1: 83-110.

Reuter, Ora John, and Thomas F. Remington. 2009. "Dominant Party Regimes and the Commitment Problem: The Case of United Russia." Comparative Political Studies 42, 4: 501-526.

Rodan, Garry, and Kanishka Jayasuriya. 2007. "The Technocratic Politics of Administrative Participation: Case Studies of Singapore and Vietnam." Democratization 14, 5: 795-815.

Sagar, Rahul. 2014. "Have You Been to Kazanistan?: The Case for Decent Regimes." Manuscript.

Schedler, Andreas. 2002. "The Menu of Manipulation." Journal of Democracy 13, 2: 36-50.

- - , ed. 2006. Electoral Authoritarianism: The Dynamics of Unfree Competition. Boulder: Lynne Rienner. 
Schneider, Ben Ross. 2013. Hierarchical Capitalism in Latin America: Business, Labor, and the Challenges of Equitable Development. New York: Cambridge University Press.

Searing, Donald D. 1985. "The Role of the Good Constituency Member and the Practice of Representation in Great Britain." Journal of Politics 47, 2: 348-381.

Seawright, J., and J. Gerring. 2008. "Case Selection Techniques in Case Study Research: A Menu of Qualitative and Quantitative Options." Political Research Quarterly 61, 2: 294-308.

Shambaugh, David L. 2008. China's Communist Party: Atrophy and Adaptation. Berkeley: University of California Press.

"Sights of Singapore: Chong Pang Meet the People Se." 2014. https:// www.youtube.com/watch?v=Odt3KstxcSI (accessed May 21, 2015).

Sim, Soek-Fang. 2006. "Hegemonic Authoritarianism and Singapore: Economics, Ideology and the Asian Economic Crisis." Journal of Contemporary Asia 36, 2: 143-159.

"Singapore Parliament Reports." 1955. Road Traffic (Amendment) Bill. November 7. http://sprs.parl.gov.sg/search/topic.jsp?current TopicID=00047317$Z Z \&$ currentPubID $=00068868-Z Z \&$ topicKey $=00068868-Z Z .00047317-Z Z$ _1\%2Bid026_19551107_S0004_T00101-bill\%2B (accessed May 21, 2015).

- - . 1968. Budget (Ministry of Labour). December 16. http://sprs.parl.gov.sg/search/topic.jsp?current TopicID=00053671-ZZ \&currentPubID=00069199-ZZ\& topicKey=00069199-ZZ.00053671ZZ_1\%2Bid018_19681216_S0003_T00051-budget\%2B (accessed May $21,2015)$.

- - 1976. Budget (Prime Minister Office). March 16. http://sprs.parl.gov.sg/search/topic.jsp?currentTopicID=00056274-ZZ \&currentPubID=00069322-ZZ\& topicKey=00069322-ZZ.00056274ZZ_1\%2Bid004_19760316_S0002_T00071-budget\%2B (accessed May $21,2015)$.

- - - 2013. Head T-Ministry of National Development. March 8. http://sprs.parl.gov.sg/search/topic.jsp?currentTopicID=00079089WA\&currentPubID=00079098-WA\& topicKey=00079098-WA.00079089WA_4\%2Bbudget\%2B (accessed May 21, 2015).

Slater, Dan. 2010. Ordering Power: Contentious Politics and Authoritarian Leviathans in Southeast Asia. Cambridge: Cambridge University Press.

Spykerman, Kimberly. 2012. "DPM Teo to Ensure Punggol East Residents' Needs Are Met." December 15. www.channelnewsasia.com/news/specialreports/parliament/news/dpm-teo-to-ensure-punggol/530192.html (accessed May 21, 2015).

Stokes, Susan C., Thad Dunning, Marcelo Nazareno, and Valeria Brusco. 2013. Brokers, Voters and Clientelism: The Puzzle of Distributive Politics. Cambridge: Cambridge University Press.

Straits Times. 1991. "No More MP Offices at HDB Void Decks," November 15. Streeck, Wolfgang, and Kathleen Thelen. 2005. "Introduction: Institutional Change in Advanced Political Economies." In Beyond Continuity: Institu- 
tional Change in Advanced Political Economies, ed. Wolfgang Streeck and Kathleen Thelen, 1-39. New York: Oxford University Press.

Svolik, Milan W. 2012. The Politics of Authoritarian Rule. Cambridge: Cambridge University Press.

“Tan Chuan-Jin's First Meet-the-People Session." 2013. YouTube video (3:38). www.youtube.com/watch?v=hRJJFNoxNY0 (accessed May 21, 2015).

Tan, Kenneth Paul. 2008. "Meritocracy and Elitism in a Global City: Ideological Shifts in Singapore." International Political Science Review 29, 1: 7-27.

- - . 2014. "The Singapore Parliament: Representation, Effectiveness, and Control." In Parliaments in Asia: Institution Building and Political Development, ed. Yongnian Zheng, Liang Fook Lye, and Wilhelm Hofmeister, 27-46. New York: Routledge.

Tan, Kenneth Paul, and Andrew Sze-Sian Tan. 2003. "Democracy and the Grassroots Sector in Singapore." Space and Polity 7, 1: 3-20.

Tan, Kevin. 2008. Marshall of Singapore: A Biography. Singapore: Institute of Southeast Asian Studies.

Tan, Netina. 2013. "Manipulating Electoral Laws in Singapore." Electoral Studies 32, 4: 632-643.

Tan, Netina, and Bernard Grofman. 2014. "Multiseat Plurality Bloc Voting in Electoral Authoritarian Regimes: Comparing Singapore, Cameroon, Djibouti, and Chad." Paper presented at AAS-in-Asia Conference 2014, National University of Singapore.

TODAYdigital. 2012. "Michael Palmer Resigns as Speaker and MP.” YouTube video (13:25). http://youtu.be/bK-eXoMpjg8 (accessed May 21, 2015).

Truex, Rory. 2014. "Representation Within Bounds." PhD diss., Yale University. www.rorytruex.com/s/rtruex-Representation-Within-Bounds -Synopsis.pdf (accessed May 21, 2015).

Tsai, Lily L. 2007. "Solidary Groups, Informal Accountability, and Local Public Goods Provision in Rural China." American Political Science Review 101, 2: 355-372.

Wedeen, Lisa. 1999. Ambiguities of Domination: Politics, Rhetoric, and Symbols in Contemporary Syria. Chicago: University of Chicago Press.

Zaobao. 2013. "Zhuan Gao: Zhong Guo Xue Zhe Dui Hua Xin Jia Po Fan Dui Dang 'Yi Ge." Zaobao.com.sg. May 22. www.zaobao.com.sg /special/zbo/others/story20130522-207333 (accessed May 21, 2015). 